\title{
Benita Laumane, Jūra latviešu valodā un folklorā: etnolingvistiskais aspekts (Morze w języku i folklorze łotewskim: aspekt etnolingwistyczny),Liepājas Universitāte Kurzemes Humanitārais Institūts, Liepāja 2013, ss. 403.
}

Opracowanie Benity Laumane Jūra latviešu valodā un folklorā: etnolingvistiskais aspekts jest pierwszym opisem pojęcia „morze” w języku łotewskim z punktu widzenia etnolingwistyki, dlatego też autorka koncentruje się przede wszystkim na badaniu systemu wyobrażeń, pojęć, realiów i ich nazw związanych z tym pojęciem na tle porównawczym. Prezentuje materiał lingwistyczny w łotewskim języku pisanym, dialektach i frazeologii w kontekście łotewskiego folkloru (pieśni, legendy, bajki, wierzenia) i mitologii.

Do analizy porównawczej materiału leksykalnego zostały włączone leksemy języków bałtyckich (litewskiego i pruskiego), bałtyckofińskich (estońskiego i liwskiego), a także języków słowiańskich (polskiego, kaszubskiego i rosyjskiego) i in.

Wszystkie przykłady opatrzono zapisem źródłowym. Bez odesłania do źródeł pozostała część nieopublikowanych materiałów zebranych przez autorkę. Materiał językowy reprezentujący dialekty i gwary zapisano w transkrypcji fonetycznej. Przykłady łotewskie pochodzące z dawnych źródeł zapisanych starą ortografią dla ułatwienia odbioru podano w transliteracji.

W trakcie analizy autorka wykorzystała również materiały i metodologię ze swoich wcześniejszych prac (od 1973 roku).

Monografia składa się z krótkiego wprowadzenia, wstępu, rozdziału wprowadzającego oraz pięciu rozdziałów tematycznych.

W rozdziale wprowadzającym JÜRA un MARE baltu valodās (MORZE i MARE w językach bałtyckich) autorka zwraca uwagę na dawne znaczenie słowa jūra 'wielka woda', zachowane głównie w klasycznych łotewskich pieśniach ludowych. Pokazuje też lokalizację leksemu mare na terytorium Łotwy i jego desemantyzację we współczesnym języku łotewskim.

W rozdziale Piekrastes iedzìvotāji (Mieszkańcy wybrzeża) dokonuje analizy nazw (zarówno neutralnych, jak i ekspresywnych) mieszkańców badanego obszaru i Mierzei Kurońskiej. Omawia cechy fizyczne i psychiczne, stosunek do języka, tradycji 
narodowych i religii osób, do których odnosi się leksem zvejnieks 'rybak', ich sposób życia, pracę i stosunek do pracy. Analizuje również nazwy należące do pola semantycznego zvejnieku sievas 'żony rybaków' i burvji 'czarownicy', a także przezwiska mieszkańców wybrzeża.

W rozdziale trzecim Piekrastes pārdabiskie spēki (Siły nadprzyrodzone wybrzeża) autorka przedstawia leksemy związane z następującymi pojęciami: velni 'diabły', milži 'olbrzymy', labie un l̦aunie spēki 'dobre i złe moce', zvejas laime 'szczęście rybackie’. W kolejnym - Jūras mìtiskais personāžs (Mityczne postacie morskie) - mitologiczne bóstwa morskie: jūras māte 'matka morza', jūras jumprava 'panna morska', nāras 'rusałki' i in., jūras velns 'diabeł morski' i maldugunis 'błędny ognik'.

W rozdziale Priekšstati par jūru (Wyobrażenia o morzu) Benita Laumane poddaje analizie głównie teksty łotewskich pieśni ludowych, które charakteryzują właściwości morza: jūra - dzil kie, białe', jūras ūdens - labs, sālijs 'woda morska - dobra, słona', pie jūras aug ozols 'przy morzu rośnie dąb', jūrā Saules mājas 'w morzu dom Słońca', jūrā dieva kumelini 'w morzu konie boga', jūrā meitenes vainags 'w morzu wianek dziewczyny', jūras ogas - sarkanās ogas 'jagody morza - czerwone jagody', jūras dibenā pilis, dārgumi 'na dnie morza pałace, klejnoty', jūras pretstats - tìrums, lìdums 'wyobrażenie o morzu - pole, karczowisko', jūra - māte, pamāte 'morze - matka, macocha', jūra - zvejnieka kaps 'morze - grób rybaka'. Osobno omawia leksykę związaną z wyobrażeniami dotyczącymi powstania morza, a także symbolikę białej koszuli (baltà krekla simbolika).

W rozdziale Flora un fauna (Flora i fauna) opisuje leksemy należące do następujących pól semantycznych: akmeñi, oḷi 'kamienie, otoczaki', alğes 'algi', dzintars 'bursztyn', gliemežvāki 'muszle', medūzas 'meduzy', jūrmalas augi 'roślinność wybrzeża', jūras putni 'ptaki morskie', jūras vēzīši 'morskie skorupiaki', jūras dzīvnieki: roņi, delfini 'zwierzęta morskie: foki, delfiny', zivis 'ryby'. Obszernie (wraz z ilustracjami) przedstawia ryby morskie: akmen,plekste 'turbot', brētlina 'szprot', jürasbullis 'kur diabeł', lasis 'łosoś, lucìtis 'węgorzyca', menca 'dorsz', plekste 'flądra', rengge 'śledź, saida 'czarniak', silı̧ke 'śledź', zutis 'węgorz' (a także: bojātas zivis 'ryby zepsute', neēdamas zivis 'ryby niejadalne').

Słownictwo łotewskie związane z rybołówstwem morskim Benita Laumane zbierała od 1963 roku na łotewskim wybrzeżu Morza Bałtyckiego. Zbiory własne autorka uzupełniła materiałami z dialektologicznych prac badawczych studentów Uniwersytetu Łotewskiego i Uniwersytetu w Lipawie. Wykorzystała także kartotekę regionalizmów Instytutu Języka Łotewskiego Uniwersytetu Łotewskiego oraz materiały folklorystyczne ze zbiorów Instytutu Literatury, Folkloru i Sztuki Uniwersytetu Łotewskiego.

Materiały językowe i folklorystyczne pochodzące z innych języków autorka pozyskała $\mathrm{z}$ opublikowanych prac akademickich i popularnonaukowych, wśród których znalazły się następujące prace wydane w języku polskim: W. Boryś, H. Popowska-Taborska, Słownik etymologiczny kaszubszczyzny, t. 1-5, Warszawa 1994-2006; A. Brückner, Słownik etymologiczny języka polskiego, Warszawa 1970; A. Gieysztor, Mitologia Słowian, Warszawa 1986; D. Kisieliūnaite, K. Kukure, Pruski Cawx, litewski 
Kaukas, kuroniski Kauks - rozwój mitonimu od pierwszych wzmianek do czasów teraźniejszych, „Pruthenija” 2011, t. 6, s. 185-197; J. Maćkiewicz, Morze, „Etnolingwistyka", t. 3, Lublin 1990, s. 77-94; L. Roppel, Ma jesma od morza: poezja i proza kaszubska o morzu, Gdańsk 1961; L. Roppel, $Z$ księgi mądrości morzan. 13 centurii przysłów i powiedzonek kaszubskich o morzu, Gdańsk 1965; A. Ropelewski, Wieś rybacka Rewa w powiecie puckim, Gdańsk 1962; B. Sychta, Słownik gwar kaszubskich na tle kultury ludowej, t. 1-7, Wrocław 1968-1976; J. Treder, Frazeologia kaszubska a wierzenia i zwyczaje (na tle porównawczym), Wejherowo 1989.

Materiały dotyczące języka i folkloru łotewskiego uporządkowano tematycznie, co dało możliwość stworzenia poglądowego wyobrażenia o kulturze mieszkańców/rybaków wschodniego wybrzeża Morza Bałtyckiego, która w tej pracy obejmuje pojęcia związane z gospodarstwem domowym i pracą na morzu, relacje między jednostkami i większymi społecznościami, zwyczaje kulinarne, rzeczywistość i wyobrażenia mityczne, wierzenia i in. Terminologia dotycząca wiatrów, sztormów, fal morskich, według zapewnień autorki, zostanie zaprezentowana w odrębnym opracowaniu.

Na końcu książki zamieszczono wykaz wymienionych w monografii leksemów łotewskich, litewskich, pruskich, estońskich, liwskich, fińskich, polskich i kaszubskich, rosyjskich, niemieckich (dolnoniemieckich i górnoniemieckich i in.), duńskich, islandzkich, norweskich i szwedzkich.

Wyobrażenia Łotyszy i przedstawicieli innych narodowości o morzu - odzwierciedlone w językach, dialektach i gwarach - oraz ich rodzaje ekspresywne (neutralne, ironiczne) i funkcjonowanie w różnych sferach lub stylach (np. w języku mówionym, poezji, terminologii naukowej i profesjonalnej) mogą zainteresować szeroki krąg czytelników, między innymi filologów, kulturoznawców, dialektologów i tłumaczy.

Beata Biesiadowska-Magdziarz Instytut Slawistyki PAN

Warszawa 